\section{DIGITAL COMMONS \\ @ UNIVERSITY OF SOUTH FLORIDA}

\section{ABO: Interactive Journal for Women in the Arts, 1640-1830}

Volume 2

Issue 1 Volume 2.1 (Spring 2012): Open Access

Article 20

2012

\title{
Dutch and Flemish Masterworks from the Rose-Marie and Eijk van Otterloo Collection MFA-Houston (Nov. 13 2011-Feb. 12, 2012)
}

David Mazella

University of Houston, dmazella@uh.edu

Follow this and additional works at: https://digitalcommons.usf.edu/abo

Part of the Dramatic Literature, Criticism and Theory Commons, Educational Methods Commons, Feminist, Gender, and Sexuality Studies Commons, and the Literature in English, British Isles Commons

\section{Recommended Citation}

Mazella, David (2012) "Dutch and Flemish Masterworks from the Rose-Marie and Eijk van Otterloo Collection MFA-Houston (Nov. 13 2011-Feb. 12, 2012)," ABO: Interactive Journal for Women in the Arts, 1640-1830: Vol.2: Iss.1, Article 20. http://dx.doi.org/10.5038/2157-7129.2.1.19

Available at: https://digitalcommons.usf.edu/abo/vol2/iss1/20

This Reviews is brought to you for free and open access by Digital Commons @ University of South Florida. It has been accepted for inclusion in ABO: Interactive Journal for Women in the Arts, 1640-1830 by an authorized administrator of Digital Commons @ University of South Florida. For more information, please contact digitalcommons@usf.edu. 
Dutch and Flemish Masterworks from the Rose-Marie and Eijk van Otterloo Collection MFA-Houston (Nov. 13 2011-Feb. 12, 2012)

\author{
Keywords \\ review, visual art, visual culture \\ Creative Commons License \\ (c) $($ ) $\odot$
}

This work is licensed under a Creative Commons Attribution-No Derivative Works 3.0 License. 
Realism and Riches

Dutch and Flemish Masterworks from the Rose-Marie and Eijk van Otterloo Collection (Nov. 13 2011-Feb. 12, 2012)

Reviewed by David Mazella, University of Houston

I was lucky enough to catch an extraordinary show of seventeenth-century Flemish and Dutch paintings just as it was finishing its national tour in Houston. This show allows us to see for the first time the Van Otterloo Collection as a whole, while offering a comprehensive selection of genres and artists from this astonishingly prolific period of art production.

The sixty or so paintings on view provide an excellent opportunity to think about the term "realism" in a comparative way, placing realism between the verbal and visual arts, and allowing us to consider how genre, style, and subject matter can inflect our notions of realism.

Many conventional discussions of "realism," whether in the visual or verbal arts, tend to define it negatively, and treat it as a principled absence of style or expression. According to this view, it is all Dreiser everywhere, as far as the eye can see. This conventional view treats realism as a passive, impersonal, or transparent mode of representation, one that simply rejects the heightening or stylization freely available to other kinds of art. There is an unmistakably ascetic flavor to this argument, as artists and audiences deny themselves the whimsies, whether beautiful or grotesque, available to them through the so-called "magic" of art. But realism's rejection of the artificially-heightened image also lays the groundwork for its most important innovation in the history of art and literature: its acceptance of the low, the undignified, the everyday, the concrete, and the temporally unfinished into the realm of art. It is this acceptance of the everyday that allows realism to begin to include in its purview what lies beyond some of the traditional subject matter of art, whether that is defined as the sacred, the aristocratic, or the classical.

And yet when I walked into the gallery at Houston's Museum of Fine Arts (MFAH), the first painting that caught my eye was Aelbert Cuyp’s “Orpheus Charming the Animals” (ca. 1640), which features two leopards in the foreground who meet the gaze of the viewer a little impatiently, as if interrupted from a reverie. Their stance seems to warn the spectator not to disturb the poet's performance. The poet himself plays a viol, wears a brilliant red cloak and Greek sandals, and is surrounded by an improbable crowd of domestic and exotic animals. Two whippet-like dogs sit and listen to his songs, while a camel stands rapt and flocks of fanciful birds wheel overhead, attracted by the sound. There is, of course, an elephant in the background, foraging in the trees, not far from an ostrich on a hillside. The gallery notes tell us that the uncosmopolitan Cuyp almost certainly painted the non-European animals from stuffed specimens held in local cabinets of curiosities. But what I find most remarkable is the way in which the mythological and the exotic have been comfortably embedded in a precisely rendered landscape of trees, fields, and open sky. 


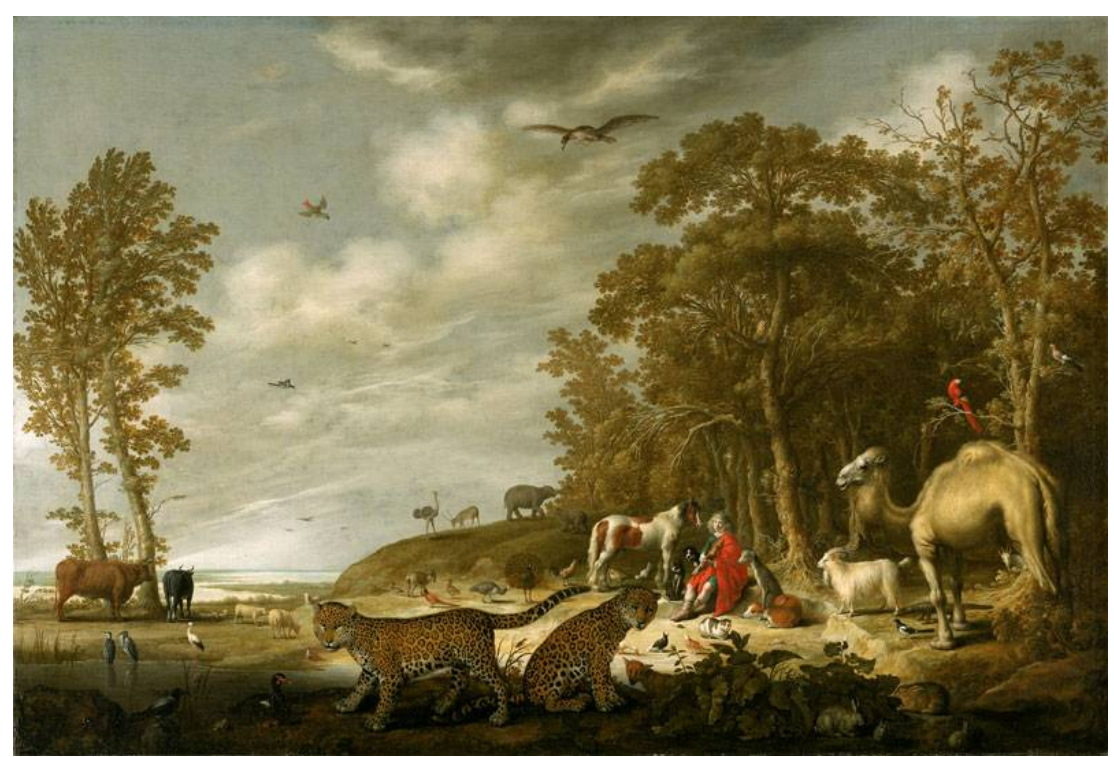

Cuyp, Orpheus Charming the Animals, c. 1640

The mix of the extravagant and the everyday in Cuyp's scene suggests that the realism I was viewing was not passively mimetic, but relational, fusing together disparate elements for the surprise and pleasure of the viewer, and in an altogether calmer, more reflective manner than in, say, the Baroque. There is nothing self-denying in these paintings' sumptuous presentation of details. The show's sequential presentation of genres helped confirm my sense of realism as relational and atmospheric, teaching us to look at the edges of the paintings for further surprises. Accordingly, varied examples of landscape, architectural, and marine paintings were assembled alongside scenes from everyday life, genre paintings, still lives, and portraits, but in each case realism dictates a certain fullness of execution to the genre, a scaling down of the central figures so that the peripheries can take on a life of their own. Hendrick Avercamp's marvelous "Winter Landscape near a Village” (ca. 1610-15) demonstrates this principle of fullness in its depiction of an entire village's population talking, skating, standing, digging around, and pushing and getting pushed across the ice on a wintry afternoon. In the lower right-hand corner, we see an elderly bearded gentleman, well bundled, who might just be the figure of winter personified. He is standing next to a shivering dog and a pair of boots left on a fence to dry.

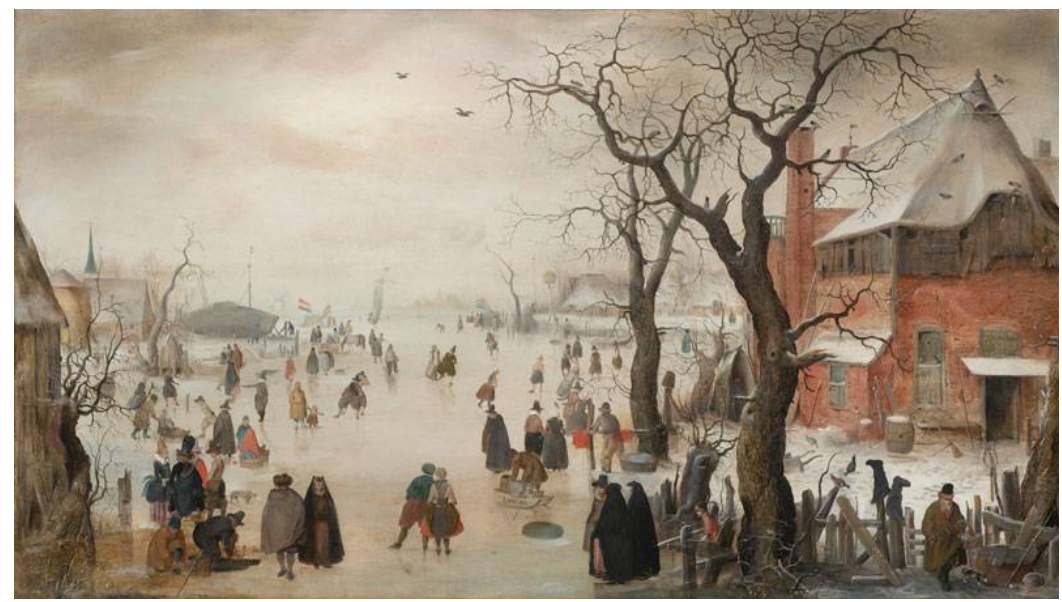

Avercamp, Winter Landscape Near A Village, c. 1610-15 
Realism therefore becomes the name we give for the pleasures of profusion, not such a foreign thought for a nation thoroughly enjoying its commercial empire, and paying hefty fees for artists to record their enjoyment of these pleasures. And yet there are moralistic, even Mandevillean reflections on the duplicity or impermanence of pleasures, as well, like Nicolaes Maes's “Sleeping Man Having His Pockets Picked” (c. 1655), or Wilem Claesz. Heda’s "Still Life with Glasses and Tobacco" (1633). Claesz. Heda gives us the scene of pleasure from the perspective of the morning after, complete with overturned glasses, scraps of food, and heaps of tobacco and pipes.

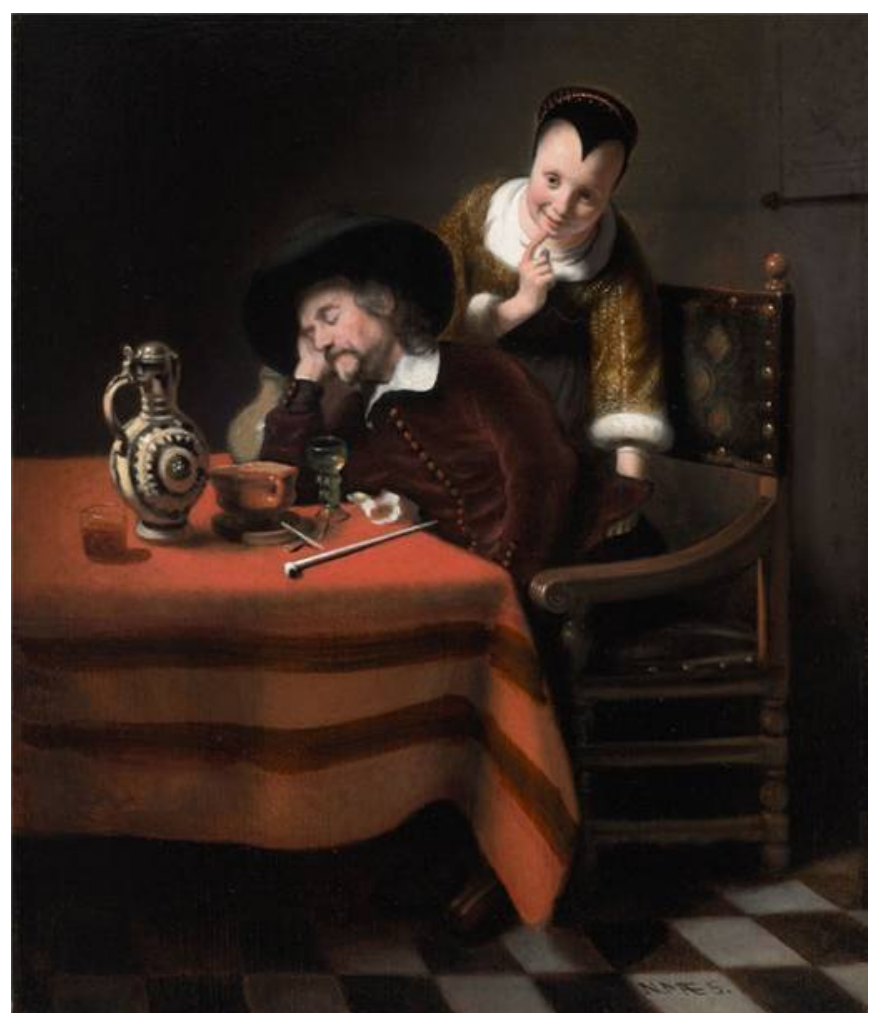

Maes, Sleeping man having his pockets picked, c. 1665

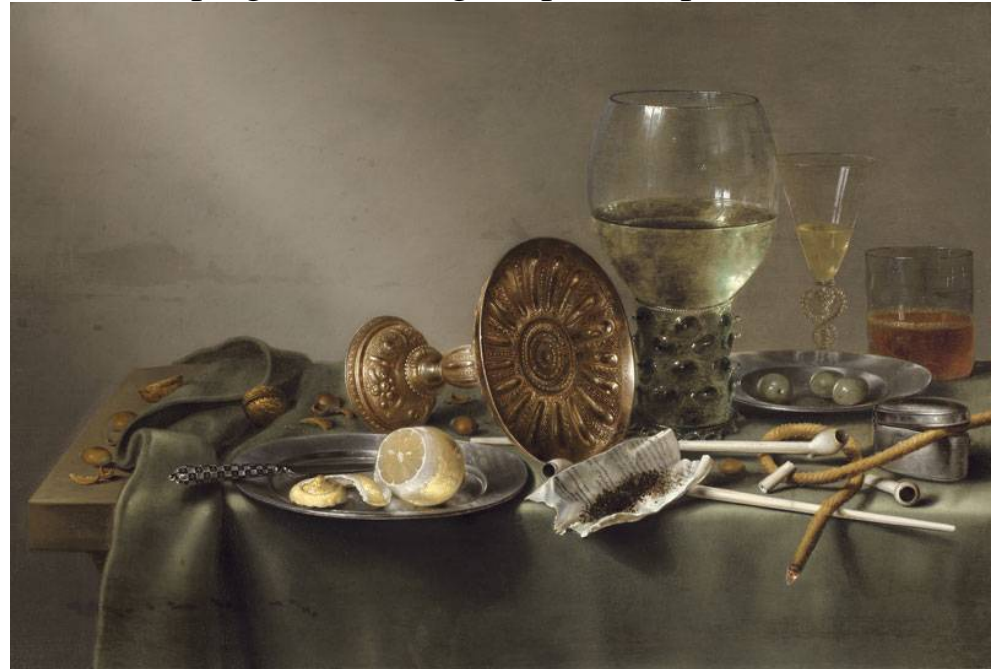

Heda, Still Life with Glasses and Tobacco, 1633 
In an exhibit that contains too many fine paintings to describe in detail, including portraits by Rembrandt and Hals, I want to conclude with the undoubted crowd-pleaser of the exhibition: Gerrit Dou's “Sleeping Dog” (1650). This is an amazingly subtle and individualized portrait of a dog sleeping on a tabletop (its eyes are half-closed, its paws folded up underneath its body) next to a ceramic pot and a bundle of twigs. It is only a "still life" for the duration of the dog's nap. The delicacy of the texture and coloring of its fur, the reflected light on the ceramic pot, the distinct textures of the twigs and the basket in the background, all these suggest the artist's ability to render the life and personality of an animal vividly against a carefully delimited backdrop of brown, red-orange, and grey tones. This extraordinarily sympathetic, yet unsentimental portrait (the dog here is palpably doggish and un-anthropomorphized) falls in line with the matter-of-fact presentation of humans and animals together in many other paintings, from Cuyp's mythological tableau to Koninck's cattle and sheep getting peacefully transported on river barges.

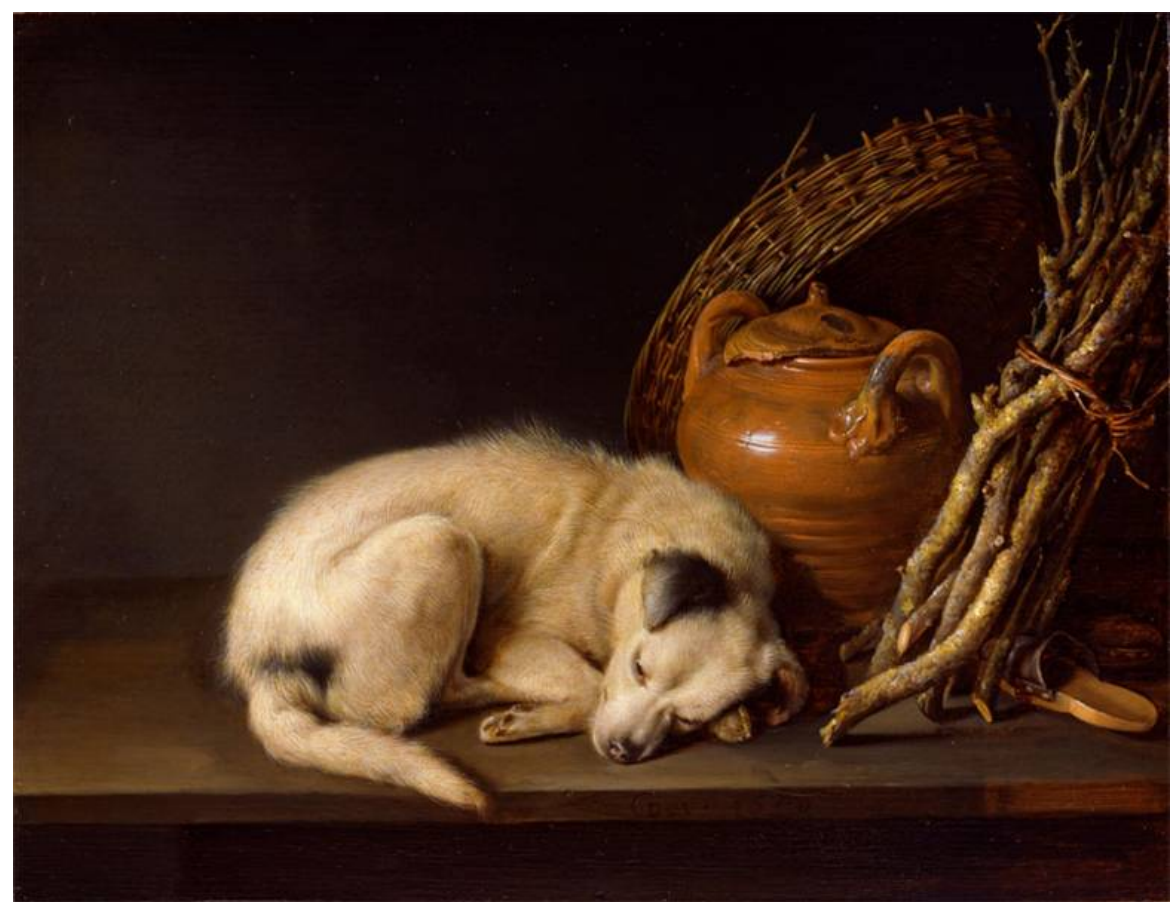

Dou, Sleeping Dog, 1650

The satisfaction of viewing a collection like the van Otterloo's comes from an appreciation of the patience and integrity of its curation over the years. The van Otterloos, a Dutch-Flemish couple who have lived in New Hampshire together for most of their lives, have maintained the oldworld tradition of living with their collection, and this kind of intimate knowledge of, and contact with, their paintings seems to have given them the ability to understand when a particular piece, like the Cuyp Orpheus, belongs with the others, even when a more literal-minded collector might have rejected it. Nonetheless, the assembled pieces here suggest a view of realism that is more capacious than we might ordinarily expect, and as interested in delivering subtle and unexpected pleasures as the humble delineation of "the real." 